\title{
MASTRR.
}

ORNL/TM-6619

\section{Determination of End-of-Life-Failure Fractions of HTGR-Fuel Particles by Postirradiation Annealing and Beta Autoradiography}

\author{
B. A. Thiele \\ M. Herren
}




\section{DISCLAIMER}

This report was prepared as an account of work sponsored by an agency of the United States Government. Neither the United States Government nor any agency Thereof, nor any of their employees, makes any warranty, express or implied, or assumes any legal liability or responsibility for the accuracy, completeness, or usefulness of any information, apparatus, product, or process disclosed, or represents that its use would not infringe privately owned rights. Reference herein to any specific commercial product, process, or service by trade name, trademark, manufacturer, or otherwise does not necessarily constitute or imply its endorsement, recommendation, or favoring by the United States Government or any agency thereof. The views and opinions of authors expressed herein do not necessarily state or reflect those of the United States Government or any agency thereof. 


\section{DISCLAIMER}

Portions of this document may be illegible in electronic image products. Images are produced from the best available original document. 
Printed in the United States of America. Available from National Technical Information Service

U.S. Department of Commerce

5285 Port Royal Road, Springfield, Virginia 22161

Price: Printed Copy $\$ 4.00$; Microfiche $\$ 3.00$

This report was prepared as an account of work sponsored by an agency of the United States Government. Neither the United States Government nor any agency thereof, nor any of their employees, contractors, subcontractors, or their employees, makes any warranty, express or implied, nor assumes any legal liability or responsibility for any third party's use or the results of such use of any information. aoparatus. product or process disclosed in this report, nor represents that its use by such third party would not infringe privately owned rights. 
ORNL/TM-6619

Distribution

Category UC-77

Contract No. W-7405-eng-26

METALS AND CERAMICS DIVISION

HTGR BASE TECHNOLOGY PROGRAM

Fueled Graphite Development (189a 01330)

DETERM INATION OF END-OF-LIFE-FAILURE FRACTIONS OF HTGR-FUEL

PARTICLES BY POSTIRRADIATION ANNEALING AND

BETA AUTORADIOGRAPHY

B. A. Thiele and M. Herren

Date Published: November 1978

This report was prepared as an account of work sponsored by the United States Government. Neither the United States nor the United States Department of Energy, not any of their employees, nor any of their contractors, subcontractors, or their employees, makes any werrenty, express or implied, or assumes any legal liability or responsibitity for the accuracy, completeness or usefulness of any information, apparatus, product or process disclosed, or represents that its use would nol infringe privately owned rights.

\footnotetext{
OAK RIDGE NATIONAL LABORATORY

Oak Ridge, Tennessee 37830

operated by

UNION CARBIDE CORPORATION

for the

DEPARTMENT OF ENERGY
} 
THIS PAGE

\section{WAS INTENTIONALLY \\ LEFT BLANK}


CONTENTS

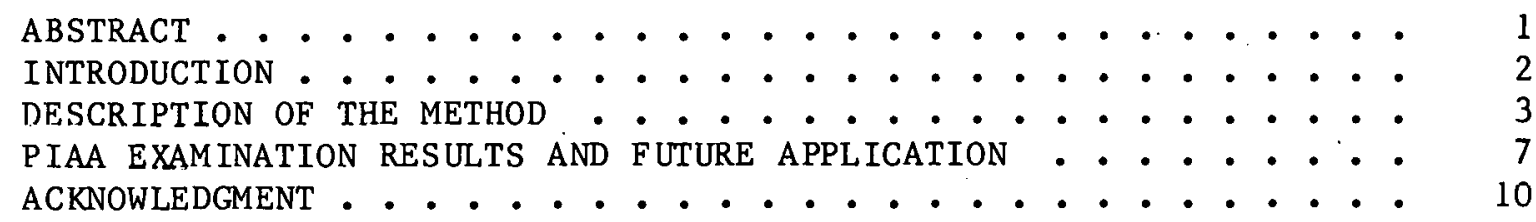


DETERMINATION OF END-OF-LIFE-FAILURE FRACTIONS OF HTGR-FUEL PARTICLES BY POSTIRRADIATION ANNEALING AND BETA AUTORADIOGRAPHY

(Description of the PIAA-Technique)

B. A. Thiele ${ }^{1}$ M. Herren ${ }^{2}$

ABSTRACT

Fission-product contamination of the helium coolant of High-Temperature Gas-Cooled Reactors (HTGR) is strongly influenced by the end-of-life (EOL) failed-particle fraction. Knowledge of the EOL-failure fraction is the basis for model calculations to predict the total fission product release from the reactor corc.

After disintegration of irradiation fuel rods, fuel particles are placed in individual holes of a graphite tray. During a $5-\mathrm{h}$ heat treatment at $1000^{\circ} \mathrm{C}$ in a helium atmosphere failed particles leak fission products, especially the volatile cesium, into the graphite. After unloading, a $\beta-$ autoradiograph of the tray is made. Holes that housed defective particles are identified from black spots on the $\beta$-sensitive film. The EOL-failure fraction is the ratio of defective particles to the total number of particles tested. The technique is called PIAA, Postirradiation Annealing and Autoradiography.

The PIAA technique was applied to particles of a Trisocoated highly-enriched $\mathrm{UO}_{2}$ fissile batch irradiated to a burnup of $35 \%$ FIMA at an irradiation temperature of $1250^{\circ} \mathrm{C}$. Visual examination showed all particles to be intact. From 11 to $47 \%$ of the particles had failed, as determined by PIAA. Further, postirradiation examination showed that localized corrosion of the silicon carbide coating by fission-product rare-earth chlorides had occurred.

The PIAA technique is an accurate, reliable, quick, and inexpensive procedure for measurement of statistically significant failure fractions in the range from $10^{-4}$ to $10^{-3}$ in irradiated Triso-coated fuel particles for HTGRs.

\footnotetext{
1 On assignment from Institut für Reaktorwerkstoffe, Kernforschungsanlage Jülich GmbH, West Germany.

${ }^{2}$ Heisse Zellen/Institut für Reactorwerkstoffe Staff Member.
} 


\section{INTRODUCTION}

The helium-coolant circuit of High-Temperature Gas-Cooled Reactors is contaminated by gaseous and solid fission product release from fuel particles. The fission products released stem from (1) the contamination of the coating of the fuel particles and the matrix materials with fissionable material, (2) defective coatings of as-produced fuel particles [beginning-of-life (BOL) failure fraction], and ( 3 ) the fuel particles that fail during the operation of the reactor. Both contamination and BOL failure fraction are low, each about $10^{-5}$ of the total fissionable material inventory. These values are determined routinely. 3 Under normal reactor operating conditions, end-of-life (EOL)-failed particle fraction is low too, about $10^{-3}$ to $10^{-4}$. This quantity is not only a function of temperature, burnup, and fast fluence that the individual particles experience in their lifetime but is also affected by the statistical variations of the particle geometry and properties within the production batch. Knowledge of the influence of these parameters on the EOL-failure fraction is the basis for model calculations to predict the total fission release of the reactor core. It is understood that "failed" particles do not necessarily release their total fission product inventory. Release depends upon the parricle temperature, the integrity and composition of the kernel, and the type and extent of the fuel particle failure. Because of the above factors, fission product release is very selective, partial, and timedependent. As an example, carbide kernels release rare-earth fission products while oxide kernels retain them.

Since the main objective of a biso pyrocarbon coating is to retain the gaseous-fission products, Biso fuel particles are declared "failed" when the fission-gas inventory is lost thrnugh rrarks or gas-permeable PyC. Triso particles have an additional SiC layer to effectively retain the solid fission products. Of all solid fission products, cesium

3D. E. LaVelle, D. A. Costanzo, W. J. Lackey, and A. J. Caputo, The Determination of Defective Particle Fraction in HTGK Fuels, ORNL/TM5483 (November 1976). 
is the most volatile and abundant. Thus, Triso particles are declared failed when they lose part of their cesium inventory.

Failed Triso particles do not lose their whole cesium inventory during irradiation. Irradiated particles placed in individual holes of a graphite disk leak solid fission products (preferentially cesium) during short-term annealing. Cesium from failed particles can be detected by autoradiography of the graphite disk. The PIAA technique (postirradiation annealing and autoradiography) is based on these observations. It is used to determine EOL-failure fractions of Triso-coated HTGR fuel particles.

\section{DESCRIPTION OF THE METHOD}

Figure 1 shows the flowsheet of the PIAA technique for bonded fuel particles. Only routine hot cell operations are required.

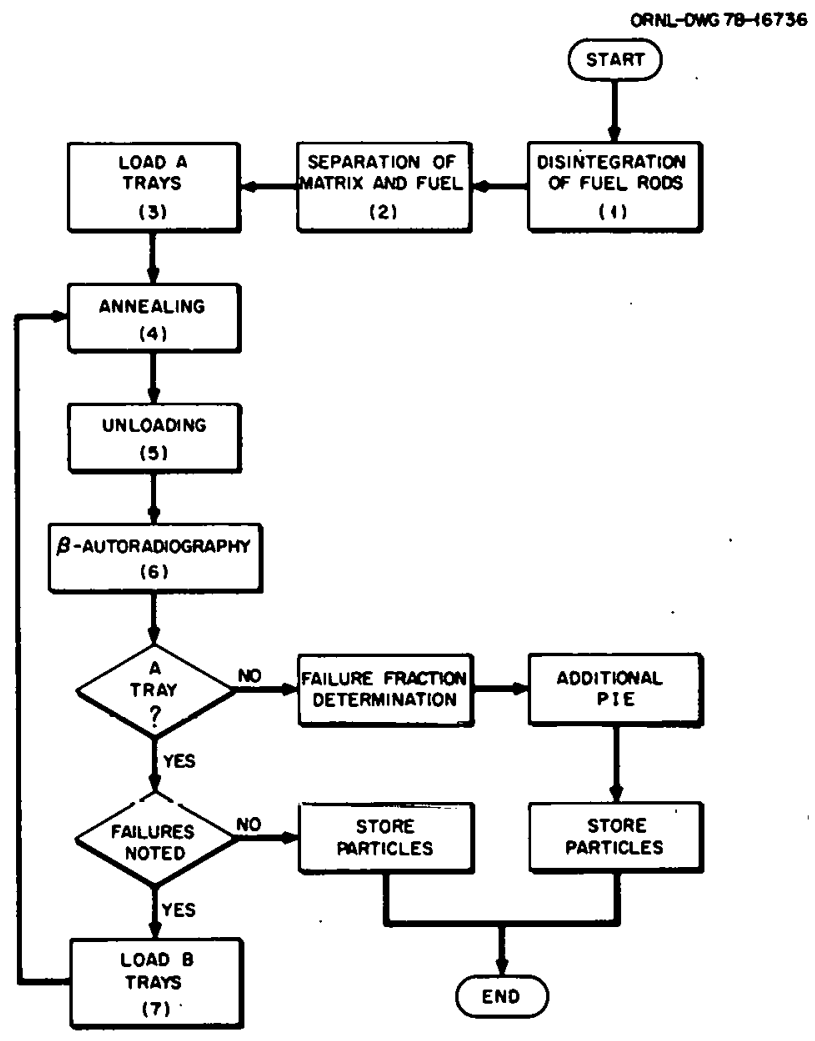

Fig. 1. Failure-Fraction Detection on Bonded Fuel Particles by PIAA Technique Requires only Routine Hot Cell Operations. 
$\underline{\text { Step } 1}$

Bonded fuel (rods, compacts, or balls) can be disintegrated electrolytically in nitric acid. 4 The conditions have to be chosen to avoid attack of the particles.

Fuel planchets (monolayer compacts) are disintegrated chemically in a solution containing $18 \mathrm{~g}$ of ammonium persulfate in $40 \mathrm{ml}$ of $98 \%$ sulfuric acid. The nitric acid electrolyte and the persulfate solution used to diṣintegrate. the bonded fuel are then analyzed for heavy metal content to determine the number of failed particles whose kernels have been dissolved.

$\underline{\text { step } 2}$

After disintegration, the particles and matrix material are transferred to a beaker and repeatedly washed with water. The particles sink to the bottom and the graphite floats on the surface. The particles are easily separated from the matrix material. The matrix material with particle fragments is checked for heavy metal content by gamma spectrometry.

Step 3

Particles are poured from the storage container into the particle selector (see Fig. 2). The selector is a container that has a false bottom with 100 individual 0.5 -mm-diam holes, below which a vacuun is applied so that 100 particles are trapped at the holes. The excess particles are poured back to the particle storage. The 100 particles retained in the selector are now poured into the particle hopper by rotating the selector in the opposite direction and discontinuing the vacuum. I'he particles are discharged from the hopper into one of the 18 blind livles of a graphite tray (graphite tray type A). The process of loading is repeated until all the holes in the A-tray are filled. Thus, a completely filled A-tray contains 1800 particlee.

Step 4

From five to ten filled graphite trays with a total of 9000 to 18,000 particles are stacked and fastened together with an unloaded

\footnotetext{
${ }^{4} \mathrm{H}$. Bildstein, and K. Knotik, "Chemical and Electrochemical Methods for the Desintegration of Graphitic Nuclear Fuel Elements," Kerntechnik 12: 554 (1973).
} 


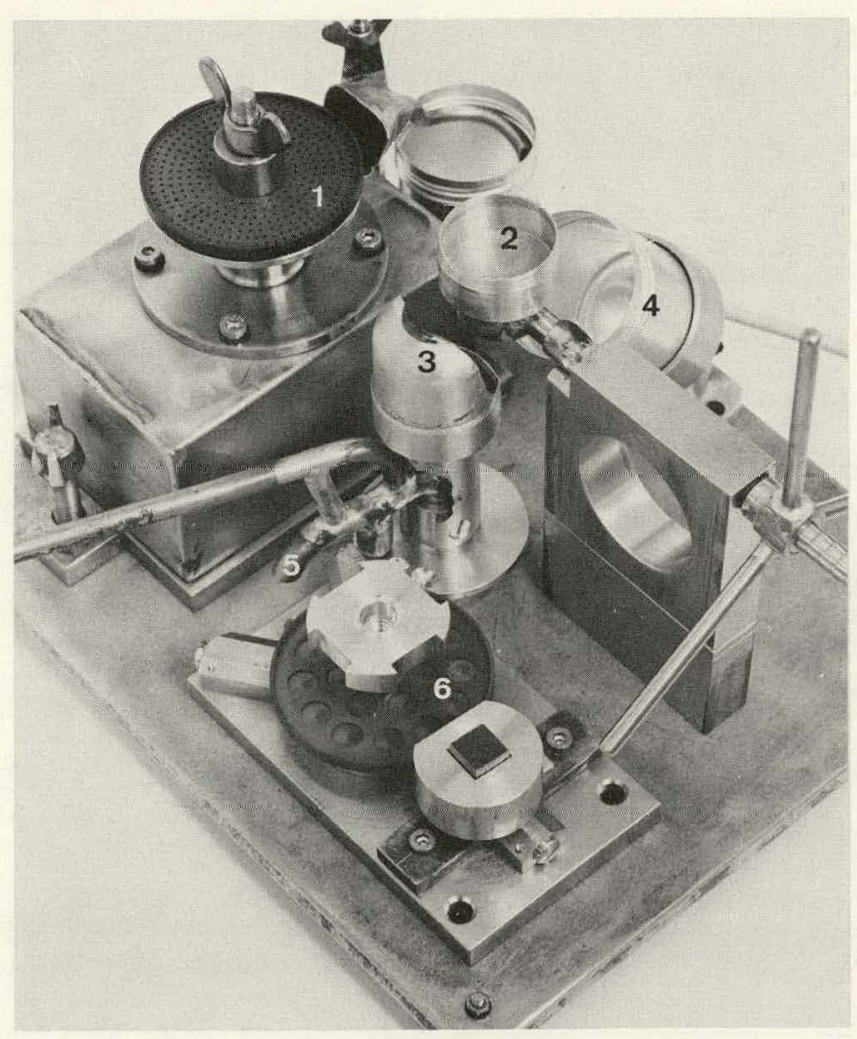

1. GRAPHITE B-TRAY WITH INDIVIDUAL HOLES

2. PARTICLE SELECTOR

3. PARTICLE HOPPER

4. PARTICLE STORAGE

5. FILLING NOZZLE

6. GRAPHITE A-TRAY WITH BLIND HOLES

Fig. 2. Sample Apportioning and Loading Device. KFA Jülich photograph.

tray on top. This arrangement is heat-treated at $1000^{\circ} \mathrm{C}$ in a helium atmosphere for $5 \mathrm{~h}$. Fission gas release is measured during the heat treatment to determine whether or not additional particles fail. The number of additional failed particles can be quantitatively determined 5 by the increase of xenon and krypton activity in the liquid-nitrogen traps of the helium circuit caused by the rapid release of fission gases from newly failed particles. During this annealing, defective particles leak cesium into the graphite tray.

Step 5

After heat treatment the graphile A-trays are returned to the sample apportioning and loading device. There, the 100-particle samples are removed from the blind holes and stored in individual vials.

$5_{\mathrm{W}}$. Schenk, Untersuchungen zum Verhalten von beschichteten Brennstoffteilchen und Kugeibrennelementen bei störfalitemperaturen, Jü1-1490, ISSN 0366-0885 (Mai 78). 


\section{Step 6}

The A-trays are $\beta$-autoradiographed, 6 and the 100-particle batches containing failed particles are identified. Particles are annealed in graphite A-trays to screen large numbers of particles. A second annealing is necessary to identify individual failed particles.

\section{Step 7}

The samples containing failed particles are distributed onto the surface of a B-tray, which is a graphite disk having 320 individual holes. Each hole accommodates only one fuel particle. The B-tray is fixed to a vibrator. Vibratory motion is applied to cause the particles to settle into some of the 320 holes in the tray. Each particle is now identified with a specific hole in the tray. This is checked visually with a periscope.

Step 8

Five to ten graphite B-trays are now stacked and fastened together with an unloaded tray on top, and the heat treatment described in Step 6 is repeated.

Step 9

After heat treatment the graphite B-trays are disassembled. A Btray is placed in contact with another plate (storage tray) having an identical pattern of holes. The pair of plates is turned upside down so that the particles from the B-tray fall into the corresponding positions in the storage tray.

Step 10

The B-trays are $\beta$-autoradiographed to locate failed particles. SLep 11

The storage Lray is placed on the "Individual Particle Selector" (Fig. 3). The individual particle selector is a system in which a vacuum-particle-retrieval head can he indexed to specific hole positions on the storage tray. Particular particles identified as failed can then be selected for further failure studies like x-ray microradiography, scanning electron microscopy, and metallography.

${ }^{6}$ Kodak "High Resolution Film" or Kodak "Industrex, Kodirex," or "Cristalex" $\beta$-ray sensitive films. Exposure time 30 to $1.20 \mathrm{~s}$. 


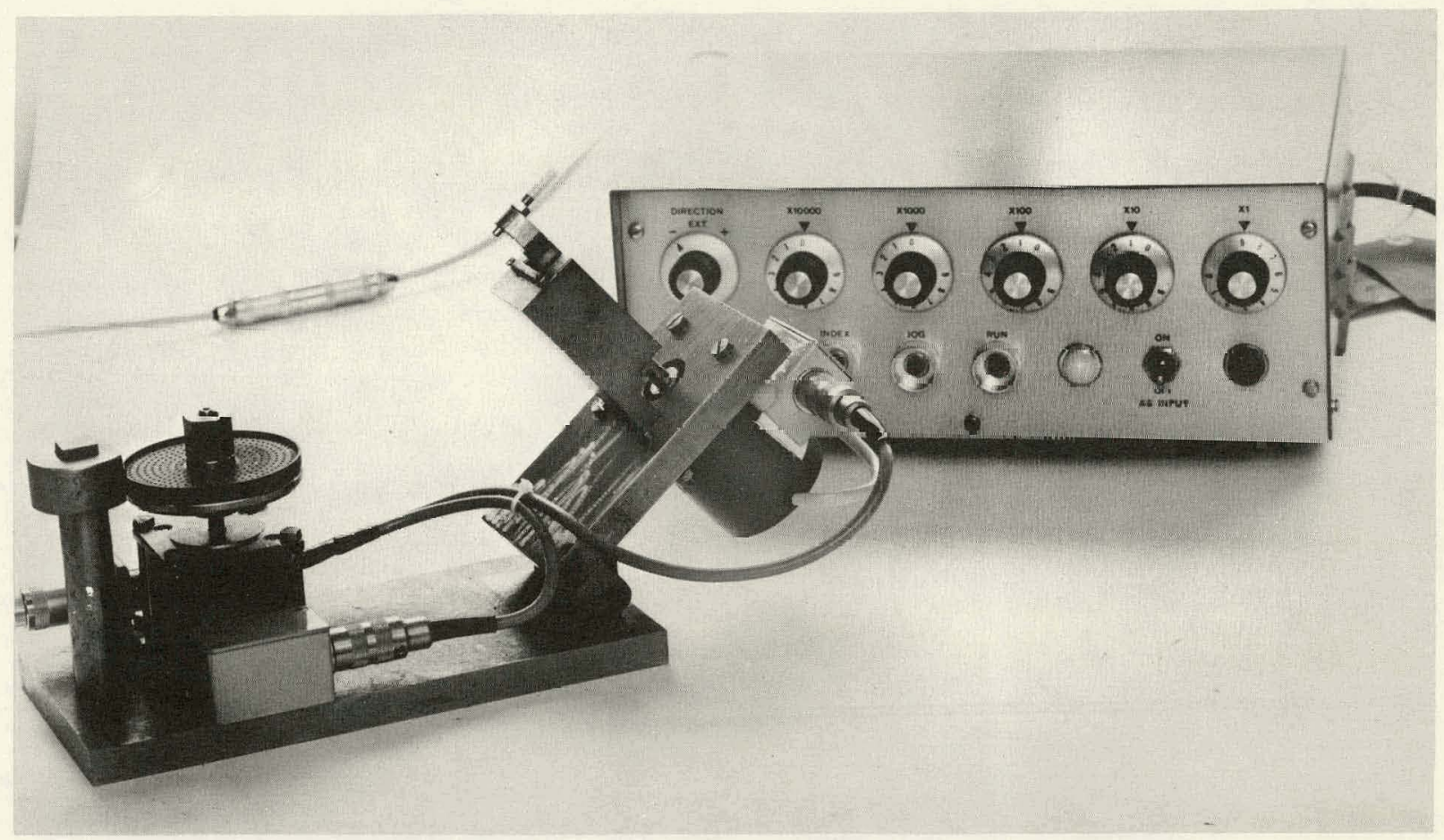

Fig. 3. Individual Particle Selector. KFA Jïlich photograph.

PIAA EXAMINATION RESULTS AND FUTURE APPLICATION

The PIAA technique was applied to particles of a Triso-coated highly enriched $\mathrm{UO}_{2}$ fissile batch irradiated in the Dido Reactor at Kernforschungsanlage Jülich. In this experiment (FRJ2-P18) loose particles of one batch were irradiated in ten graphite trays stacked together in one column. The achieved burnup was about 35\% FIMA; the irradiation temperature was $1250^{\circ} \mathrm{C}$. The visual examination showed all particles to be intact. The particles were then placed in graphite Btrays and heat-treated at $1000^{\circ} \mathrm{C}$ in a helium atmosphere for $5 \mathrm{~h}$. The trays were autoradiographed after unloading. Figure 4 shows $\beta-$ autoradiographs of three different graphite trays. The dark spots on the film indicate the positions of failed particles, which released fission product $\beta$ - and $\gamma$-emitters into the graphite. The different numbers of failed particles were caused by differences in the irradiation temperature at the bottom, the center, and the top of the irradiation capsule. 

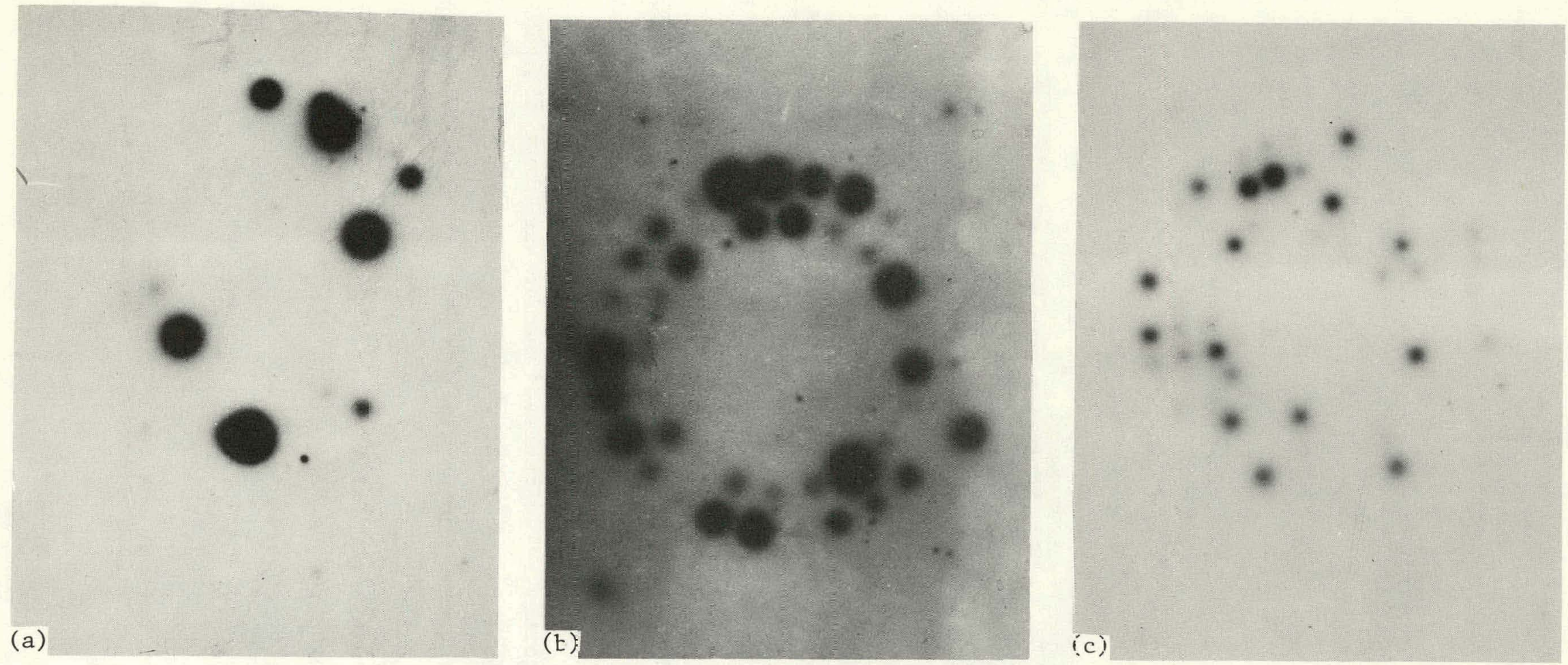

Fig. 4. After Irradiated Fuel Particles are Annealec in Graphite Trays, Autcradiography of the Empty Trays Locates the Defective Particles Heving Leaked Fissicn Products. (a) Eotton of the capsule; 8 out of 70 particles defective. (b) Center of the capsule; 33 out of 70 particles defective. (c) Top of the capsule; 29 out of 70 particles defective. KFA Jülich phozographs. 
Further postirradiation examination should reveal the type of failure that occurred to these particles. Some particles were taken out of the trays after they were identified as failed by the PIAA technique. Scanning electron microscopy and $x$-ray microradiography could not find microcracks in the coating or amoeba migration of the kernel. The outer pyrocarbon layer of the particles was then etched away in a solution of $40 \mathrm{~g} \mathrm{CrO}_{3}, 75 \mathrm{ml} 65 \% \mathrm{HNO}_{3}$, and $35 \mathrm{ml} \mathrm{H}_{2} \mathrm{O}$ to allow an inspection of the SiC layer. Scanning microscopy showed voids in the outer surface of the SiC layer [Fig. 5(a)], which were caused by local rare-earth chloride corrosion of the inner surface of the SiC layer. This corrosion was then identified in a metallographic examination [Fig. 5(b)] and microprobe analysis. ${ }^{7}$

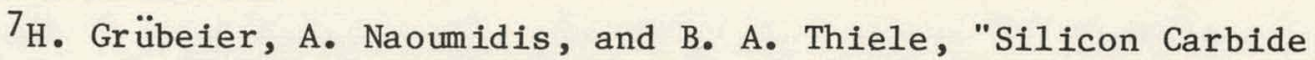
Corrosion in HTGR Fuel Particles," Nucl. Technol. 35: 413-27 (1977).
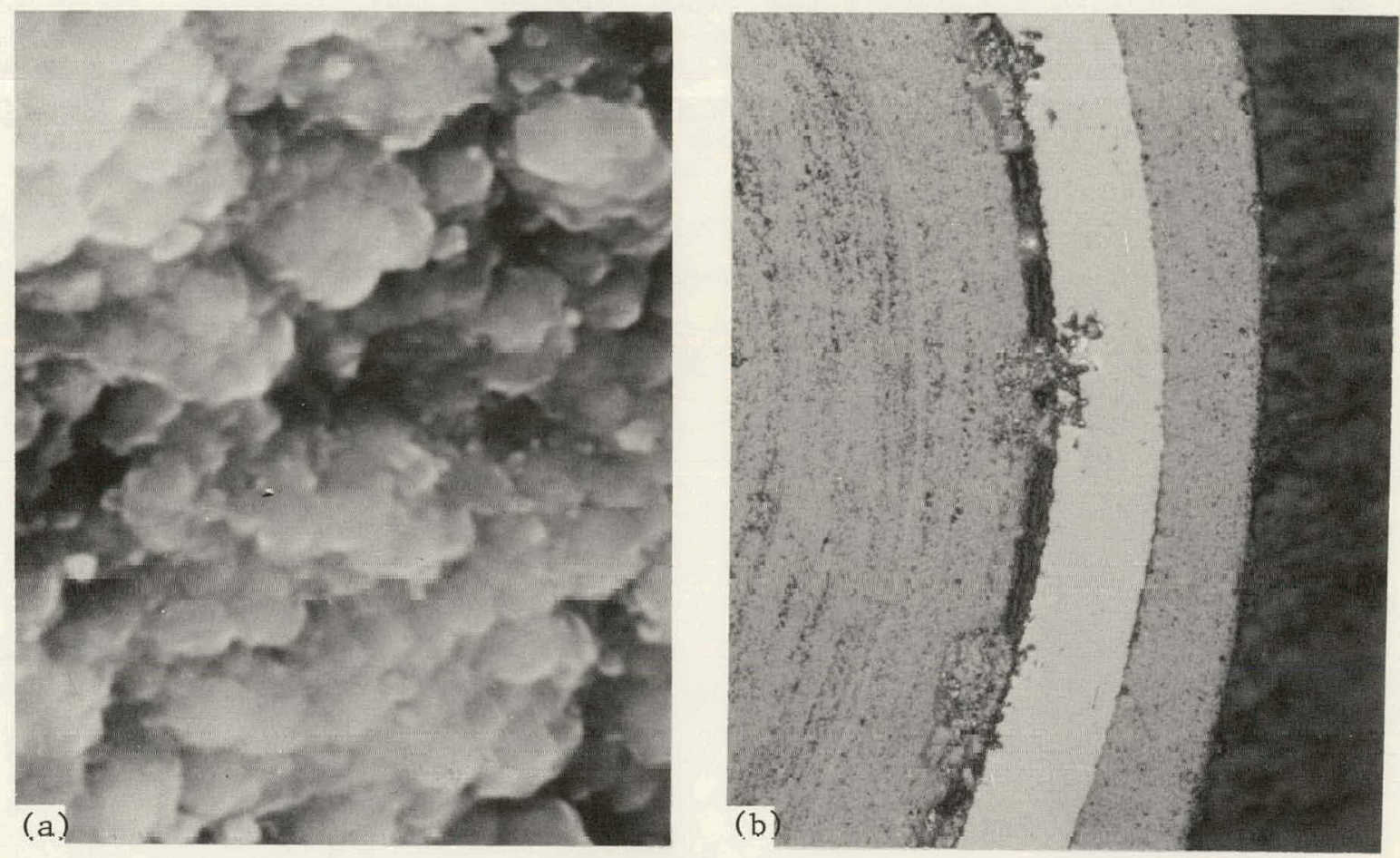

Fig. 5. Discovery of Failure Mechanism in Irradiated Triso Particle. (a) Scanning electron micrograph showing voids in the outer surface of the SiC layer. 5000x. (b) Cross section showing local rareearth chloride corrosion of the inner surface of the SiC layer. 500. KFA Jülich photographs. 
The PIAA technique is an accurate, reliable, quick, and inexpensive procedure for the measurement of statistically significant failure fractions in the range from $10^{-4}$ to $10^{-3}$ of irradiated coated fuel particles for the High-Temperature Gas-Cooled Reactor. Since this technique is based on solid fission product release from fuel particles the failure criterion for Triso-coated fuel particles - and the detection of this release, it is especially worthwhile to apply this technique on Triso-coated fissile and fertile fuel. The PIAA technique cannot be used to determine defective low-temperature isotropic (LTI) Biso-coated fuel particles since the failure criterion for these particles is the loss of fission gas and not the loss of solid fission products. Thus, particles with gastight pyrocarbon coating would be declared "failed" in case of a cesium breakthrough. On the other hand, high-temperature isotropic (HTI) Biso-coated particles have to meet both failure criteria of gastightness and retention of cesium. Therefore, PIAA could find the fraction of particles that leaked cesium, but another technique would be required to test for gastightness.

\section{AC KNOWLEDGMENT}

The authors wish to express their appreciation to J. Schunck for the design and construction of the remotely operable PIAA equipment and to S. Peterson for editing and Connie Harrison for preparing the manuscript for reproduction. 
ORNL/TM-6619

Distribution

Category UC-77

\section{INTERNAL DISTRIBUTION}

1-3. Central Research Library

4. Document Reference Section

5-7. Laboratory Records Department

8. Laboratory Records, ORNL RC

9. ORNL Patent Office

10. R. L. Beatty

11. R. A. Bradley

12. A. J. Caputo

13. J. A. Carpenter, Jr.

14. G. L. Copeland

15. D. A. Costanzo

16. F. F. Dyer

17. W. P. Eatherly

18. J. I. Federer

19-23. M. Herren

24-26. M. R. Hill

27. F. J. Homan

28. D. R. Johnson

29-38. P. R. Kasten

39. W. J. Lackey

40. R. J. Lauf

41. T. B. Lindemer
42. E. L. Long, Jr.

43. A. L. Lotts

44. J. E. Mack

45. A. P. Malinauskas

46. R. W. McClung

47. C. S. Morgan

48. A. R. Olsen

49. M. F. Osborne

50. R. L. Pearson

51. 3. E. Selle

52. D. P. Stinton

53-57. B. A. Thiele

58. S. M. Tiegs

59. T. N. Tiegs

60. R. W. Balluffi (Consultant)

61. P. M. Brister (Consultant)

62. W. R. Hibbard, Jr. (Consultant)

63. M. J. Mayfield (Consultant)

64. N. E. Promisel (Consul.tant)

65. J. T. Stringer (Consultant

EXTERNAL DISTRIBUTION

66-67. DOE DIVISION OF NUCLEAR POWER DEVELOPMENT, Washington, DC 20545 Director

68. DOE IDAHO OPERATIONS OFFICE, P.O. Box 2108, Idaho Falls, ID 83401 Barry Smith

69. SAN-DEVELOPMENT, SAN DIEGO AREA OFFICE, P.O. Box 81325, San Diego, CA 92138

Senior Program Coordinator

70, DOE SAN FRANCISCO OPERATIONS OFFICE, 1333 Broadway, Wells Fargo Building, Oakland, CA 94612

Manager

71. DOE OAK RIDGE OPERATIONS OFFICE, P.O. BOX E, Oak Ridge, TN 37830 Assistant Manager, Energy Research and Development 
72-248. DOE TECHNICAL INFORMATION CENTER, P.O. BOX 62, Oak Ridge, TN 37830

For distribution as shown in TID-4500 Distribution Category, UC-77 (Gas-Cooled Reactor Technology). 